\title{
The system of tax incentives in regional tax policy
}

\author{
Andrey Glotko, and Gennady Lyaskin* \\ Novosibirsk State University of Economics and Management, Novosibirsk, Russia
}

\begin{abstract}
The article analyzes the problem of optimization of tax benefits in formation of tax policy at the regional level. The application of a systematic approach in improving the regional tax regime has been substantiated. The content and functions of tax benefits have been determined. The classification of tax incentives is presented. The characteristic of the tax policy of the Altai Republic is given on the basis of the recommendations of the Ministry of Finance of the Russian Federation. The structure and dynamics of tax expenditures in the budget of a constituent entity of the Russian Federation are analyzed. The orientation of the tax policy of the Altai Republic towards improving regional legislation with the continuation of the course towards creating favorable conditions for development of entrepreneurship and stimulating the investment attractiveness of the region is revealed. A number of offers for improving the tax policy of the Altai Republic in terms of optimizing the system of tax incentives have been substantiated.
\end{abstract}

\section{Introduction}

Taxes are the main source of formation of the revenue side of the state, regional and municipal budgets. In addition, taxes play an important role in solving the problems of the country's socio-economic development, ensuring its stability and economic security.

Regional types of taxes and fees are most susceptible to volatility when significant changes in tax legislation are adopted. Tax incentives for regional and local taxes are an important tool contributing to the stabilization of the socio-economic situation in the region. In this regard, the study of tax incentives as a key element in the implementation of tax policy is highly relevant.

The ultimate goal of the study presented in the article is to develop recommendations for improving the regional tax policy in terms of providing tax benefits in the Altai Republic.

\section{Study Methods}

A systematic approach to solving the stated problem shall be understood as an interconnected set of goals, principles, procedures established in provision of tax incentives

\footnotetext{
${ }^{*}$ Corresponding author: g.g.lyaskin@,nsuem.ru
} 
for regional taxes, which would take into account, first of all, the interests of the regional budget.

A systematic approach to the application of tax incentives at the regional level involves considering the following principles:

1. The principle of self-sufficiency, which means that tax incentives shall generate additional revenues that will eventually compensate for the shortfall in budget revenues.

2. The principle of debt sustainability. Effective tax incentives shall not lead to an increase in the debt burden of a constituent entity of the Russian Federation.

3. The principle of inter-budgetary incentives, which means creating incentives for cancelation of ineffective tax incentives.

Implementation of the listed principles allows us to introduce a systematic approach in formation of tax policy at the regional and municipal levels.

In accordance with the Tax Code of the Russian Federation, a tax is understood as "a mandatory, individually gratuitous payment collected from organizations and individuals in the form of alienation of funds belonging to them by right of ownership, economic management or operational management of funds in order to financially support the activities of the state and (or) municipalities" [1].

Thus, taxes are an integral part of the economic relations of any society necessary for effective state regulation of socio-economic relations. Tax payments constitute the resource base of the budget of any level - federal, regional and local.

Regulation of tax revenues of regional budgets is carried out in accordance with Art. 56 of the RF and the budgets of settlements in accordance with Art. 61 of the Budget Code of the Russian Federation. Regional taxes and fees obviously play a decisive role in the formation of regional budgets. In this connection, it is more expedient to levy regional taxes at the regional level, taking into account the peculiarities of the socio-economic development of a certain region, since such payments make it possible to form the financial basis of a constituent entity of the federation necessary for its development and ensuring the well-being of its population.

According to A.V. Bryzgalin, "a tax benefit is an exclusive opportunity provided by legislation to fully or partially exempt from paying tax in presence of an object of taxation, as well as other mitigation of the tax burden for the taxpayer" [2].

I.A. Mayburov defines a tax benefit as "an optional element characterizing the provision by tax legislation to certain categories of taxpayers (payers of levies) exceptional benefits, including the ability not to pay a tax (levy) or pay a smaller amount, as well as other mitigation of the tax burden for a taxpayer (payer of levies)" [3].

According to V.G. Panskov "a tax benefit is a full or partial exemption from taxes of a subject in accordance with the current legislation, which leads to a decrease in the taxable object" [4].

S.V. Barulin in his writings says that "tax incentives provide a set of methods, rights and obligations to reduce (full and partial) tax liabilities of a taxpayer in one form or another legally established form of tax exemptions, tax rebates and tax credits for the purpose of state regulation of the economy and solving social tasks" [5].

Having considered several definitions, one can see that each author understands the types of tax incentives in his own way, but they all do not go beyond the content established by the Tax Code of the Russian Federation, and agree that use of tax incentives can reduce the tax liability of the taxpayer.

The classification of tax benefits is no less important than their definition, since it allows to structure and analyze the tax system, assess its effectiveness, and identify overload with tax benefits.

Let us consider the most common classifications of tax benefits. 
It shall start with the fact that, depending on the level of the budget, there are three categories of benefits:

- Federal - tax benefits provided by the Tax Code of the Russian Federation;

- Regional - benefits developed at the regional level, taking into account the provisions of the Tax Code of the Russian Federation;

- Local - benefits established by the regulatory legal acts of local governments.

In addition, tax benefits can be in the form of withdrawals, discounts, exemptions.

Withdrawals imply the removal of specific objects from taxation. Depending on the time, the actions can be permanent - they are valid for an unlimited period, and point - are provided for a limited period. The coverage of beneficiaries applies to all taxpayers or to a certain category of persons. There are two options for withdrawals:

The first option - a portion of the amount that is not subject to tax is deducted from the total income or profit.

The second option of withdrawal relates to property taxes - certain types of property are removed from taxation (Article 220 of the Tax Code of the Russian Federation).

Discounts are a type of tax benefit that is expressed in a reduction in the tax base. Depending on the restrictions on the size of tax benefits, there are:

- limited-implying the exclusion of some part of the taxable base. An example of a limited tax benefit is a social deduction, which involves partial compensation for the expenses of the personal income tax payer for medical care, education, and etc.

- unlimited - allowing the possibility of complete zeroing of the tax rate. This is possible in relation to VAT on the export of goods, income tax for medical, cultural, educational institutions, etc.

- universal discounts apply to all categories of taxpayers, for example, property deduction. In another version, privileges are established for individual objects of taxation - a preferential VAT rate for certain categories of goods.

Exemptions are a type of tax benefit that involves a shift in the timing of the tax payment. There are several types: deferral and installment plan. In case of a deferral, the debt is repaid at a time with payment of the entire amount, the installment plan provides for a phased payment. Use of a tax benefit is possible for one or several taxes, which are credited to the federal budget. This applies to income tax, value added tax, water tax, excise taxes.

Investment tax credit. The advantage of this tax benefit is that the payer makes reduced tax payments over a certain period of time. At the end of this period, it is necessary to pay the accumulated debt plus interest. The privilege applies to the following types of taxes: income, land, transport, property of organizations. Loan terms - from 1 to 10 years. The company receives an investment loan in the following situations: conducts experimental design or study work, incurs expenses for technical refurbishment of production facilities; fulfills a particularly important state order, including a defense order; conducts promotional or innovative activities, for example, is engaged in development of new types of materials, raw materials; invests in projects for construction of facilities with the highest energy efficiency class; included in the register of the territorial development zone.

In accordance with the Decree of the Government of the Altai Republic dated 02.03.2020 No. 20, the Procedure for formation of the list of tax expenses and the Procedure for assessing tax expenses of the specified entity were approved. In these regulations, tax expenditures are understood to mean the shortfall in budget revenues of the territories arising from provision of tax benefits to certain categories of taxpayers.

Summarizing the regulatory and legal acts on issue of determining the methodology for assessing the effectiveness of tax expenditures, it is possible to identify another classification of tax benefits, according to the target criterion:

- social - benefits aimed at supporting certain categories of citizens; 
- technical - benefits aimed at eliminating/reducing the costs of payers who took advantage of benefits, the financial support of which is carried out in full or in part at the expense of the budgets of the constituent entities of the Russian Federation;

- stimulating - benefits aimed at attracting investment and expanding economic potential (i.e., creating new jobs, improving working conditions, and etc.). Correct and systematic use of the incentive tax incentives toolkit makes it possible to activate and develop priority sectors of the economy for the region.

Evaluation of the effectiveness of tax incentives shall be carried out in two stages: at the first stage, the expediency of tax incentives is assessed, and at the second, their effectiveness.

At the stage of determining the feasibility of tax incentives, it is important to consider the criteria that must be met by the provided tax incentives.

The criterion for the effectiveness of the tax incentive is the target indicators of the state (municipal) program, the numerical value of which is influenced by the tax incentive. At least one relevant indicator must be identified.

For tax benefits classified as non-programmatic or unallocated, the performance criterion is the result of achieving the goal determined when they were granted.

In the guidelines developed by the Ministry of Finance of the Russian Federation, special attention is paid to assessing the effectiveness of incentive tax expenditures. This category of tax benefits has the greatest risks, but at the same time, if properly applied, can bring colossal economic results. In this regard, to assess the budgetary efficiency of incentive tax benefits, it is recommended to consider the assessment of the total budgetary effect (self-sufficiency) of these tax benefits $[9,10]$.

\section{Results of the Study}

Tax policy plays an important role in the functioning of the state as a whole, it has a significant impact on all aspects of the country's activities, but most of all - on the economic field. The state, while forming its tax policy, regulates the socio-economic development of the country, the region, and influences the activities of each economic entity.

It shall be noted that the tax policy of the federal state is largely composed of the tax policy of the constituent entities of the federation. In the course of the analysis of the regional tax policy of the Altai Republic, it was found that the Ministry of Finance of the Altai Republic annually determines the main directions of budgetary and tax policy, considering the current changes in the legislation of the Russian Federation. Consider the Decree of the Government of the Altai Republic of August 14, 2018 No. 257 "On the Main Directions of the Budget and Tax Policy of the Altai Republic for 2019 and for the Planning Period 2020-2021".

According to this document, the tax policy of the Altai Republic is focused on improving local legislation on taxes and fees, while continuing to create favorable conditions for development of entrepreneurship and stimulate investment attractiveness. The main strategic guideline of tax policy is its stability and predictability.

In the period 2019-2021, the tax policy of the Altai Republic was aimed at solving the following tasks:

- stimulating the increase in investment activity and ensuring the economic growth of the Altai Republic;

- strengthening the revenue base of the consolidated budget of the Altai Republic by building up stable revenue sources and mobilizing available reserves to the budget.

The main areas of tax policy include: 
a) improving the administration of tax revenues to be credited to the consolidated budget of the Altai Republic, including through digitalization of tax administration;

b) implementation of the transition that begun on January 1, 2019, to the calculation of property tax for individuals based on the cadastral value of taxable items. In this regard, an important factor is the establishment by the representative bodies of municipalities of economically justified tax rates for the tax on property of individuals, including depending on the cadastral value of the taxable object, the type of taxable object, the location of the taxable object, types of territorial zones within the boundaries of which the object of taxation is located.

c) further improvement of the legislation of the Republic of Altai on corporate profit tax, corporate property tax, patent taxation system, regulatory legal acts of representative bodies of municipalities on the taxation system in the form of a single tax on imputed income for certain types of activities;

d) continuation of interaction between the state authorities of the Altai Republic, local self-government bodies in the Altai Republic and territorial bodies of federal state authorities in the Altai Republic in order to increase the role of property taxes in formation of the consolidated budget of the Altai Republic, including in accordance with the action plan established by the Government of the Altai Republic to increase tax and non-tax revenues to the consolidated budget of the Altai Republic;

e) increasing the level of tax collection through implementation of measures aimed at reducing tax arrears and levies to the budgets of the budgetary system of the Russian Federation;

f) implementation of measures aimed at involving citizens in entrepreneurial activity, reducing informal employment.

In the course of the analysis of the above, as well as other regulatory legal acts in the field of tax policy of the Altai Republic, it was established that such a tool as tax incentives is used quite actively. Benefits are provided for the following taxes:

- for income tax in the form of a reduced tax rate of $13.5 \%$ are provided to organizations social investors, organizations implementing investment projects of regional significance in the territory of the Altai Republic;

- on transport tax in the form of a reduced tax rate and exemption from taxation are provided to individuals holding the title of Hero of the Soviet Union, Hero of the Russian Federation who have a labor veteran certificate, have disabilities of groups 1 and 2, awarded the Orders of Glory of three degrees, orders and medals of the USSR for selfless labor and impeccable service in the rear during the Great Patriotic War, organizations social investors, social service institutions, public transport organizations of urban and suburban communications.

- for the property tax of organizations, tax incentives are provided to organizations - in relation to housing facilities and engineering infrastructure of the housing and communal complex, the financial support of the activities of which is fully or partially carried out at the expense of the republican budget of the Altai Republic and (or) local budgets on the basis of budget estimates or in the form of subsidies, to organizations - social investors, organizations - in relation to public highways of republican and local significance, organizations whose investment projects have been given the status of regional significance;

- under the simplified taxation system, a tax incentive is provided to taxpayers engaged in such types of entrepreneurial activities as forestry and logging; food production; beverage production; production of clothing, and etc.

A special place in the tax policy of the Altai Republic is occupied by the procedure for the annual assessment of the effectiveness of use of tax incentives for regional and local 
taxes. In order to analyze the economic efficiency of provision of tax incentives, the Ministry of Finance of the Altai Republic annually evaluates tax expenditures.

In accordance with the Decree of the Government of the Altai Republic dated March 05, 2020 No. 20, an assessment of tax expenses and other preferences for 2017-2019 was carried out, and a forecast for 2020 was made, the indicators for which are reflected in the below Table 1 .

Table 1. The amount of tax benefits, exemptions and other preferences in the Altai Republic.

\begin{tabular}{|c|c|c|c|c|c|}
\hline Tax name & 2017 & 2018 & $\begin{array}{c}\text { Growth } \\
\text { rate, } \%\end{array}$ & 2019 & $\begin{array}{c}\text { Growth } \\
\text { rate, } \%\end{array}$ \\
\hline Income tax & 108,022 & 80,188 & 74.23 & 83,591 & 104.2 \\
\hline Transport tax & 13,146 & 12,772 & 97.15 & 11,775 & 92.2 \\
\hline Corporate property tax & 587,568 & 651,439 & 110.8 & 362,106 & 55.6 \\
\hline $\begin{array}{c}\text { Simplified taxation } \\
\text { system (STS) }\end{array}$ & 23,176 & 18,681 & 80.6 & 21,888 & 117.2 \\
\hline Patent taxation system & 1,103 & 902 & 81.7 & 339 & 37.5 \\
\hline Total & 733,015 & 763,974 & 104.2 & 479,699 & 62.8 \\
\hline
\end{tabular}

Based on the data shown in Table 1, it was found that for 2019 the total amount of tax expenses amounted to 479,699 thousand rubles, which is 284,275 thousand rubles or $37.2 \%$ less than in 2018 , their share in the volume of tax and non-tax revenues of the consolidated budget of the Altai Republic amounted to $6.7 \%$. This fact is primarily due to the cancellation of ineffective tax incentives.

It shall be noted that during the analysis of the structure of tax benefits provided in the territory of the Altai Republic, it was found that the main share of tax expenses (in 2017 $52 \%, 2018-53.5 \%, 2019-54 \%$ ) is occupied by technical tax expenses aimed at reducing the costs of organizations, the financial support of which is fully or partially carried out at the expense of the budget.

The share of social tax expenses in 2017 was $38.4 \%$, in $2018-32.8 \%$, in 2019 $34.3 \%$.

It is worth noting that there is a very low share of incentive tax expenditures aimed at stimulating entrepreneurship and attracting investment to the region. In 2017, the share of stimulating tax incentives was $9.6 \%$, in $2018-13.7 \%$, in $2019-11.7 \%$.

To deepen the analysis of the effectiveness of the application of tax incentives in the Altai Republic, consider the structure and dynamics of tax expenditures of the subject:

Table 2. Structure and dynamics of tax expenditures by type of tax for the years 2017-2019, ths. rub.

\begin{tabular}{|c|c|c|c|c|}
\hline $\begin{array}{c}\text { Ser. } \\
\text { No. }\end{array}$ & Name of indicators & 2017 & 2018 & 2019 \\
\hline $\mathbf{1}$ & $\begin{array}{c}\text { The volume of tax and non-tax } \\
\text { revenues of the consolidated budget of } \\
\text { the Altai Republic, thousand rubles }\end{array}$ & $\mathbf{5 , 4 0 8 , 3 7 9 . 8}$ & $\mathbf{6 , 3 4 4 , 2 6 5 . 4}$ & $\mathbf{7 , 1 8 5 , 8 7 3 . 8}$ \\
\hline 1.1 & $\begin{array}{c}\text { The total amount of tax expenses, } \\
\text { thousand rubles }\end{array}$ & 733,015 & 763,974 & 479,699 \\
\hline 1.2 & $\begin{array}{c}\text { Growth rate of the amount of tax } \\
\text { expenses compared to the previous year, } \\
\text { \% }\end{array}$ & $\mathrm{x}$ & 104.2 & 62.8 \\
\hline 1.3 & $\begin{array}{c}\text { Share of tax expenses from the volume } \\
\text { of tax and non-tax revenues, \% }\end{array}$ & 13.6 & 12 & 6.7 \\
\hline $\mathbf{2}$ & $\begin{array}{c}\text { Amount of corporate income tax } \\
\text { receipts, thousand rubles }\end{array}$ & $\mathbf{8 7 8 , 0 7 0 . 1}$ & $\mathbf{1 , 0 1 5 , 1 5 1}$ & $\mathbf{1 , 1 9 8 , 6 6 1 . 5}$ \\
\hline 2.1 & $\begin{array}{c}\text { The amount of tax expenses from use of } \\
\text { a reduced rate for corporate income tax }\end{array}$ & 108,022 & 80,180 & 83,591
\end{tabular}


Continuation of Table 2.

\begin{tabular}{|c|c|c|c|c|}
\hline 2.2 & $\begin{array}{l}\text { Growth rate of the amount of tax } \\
\text { expenses for corporate income tax } \\
\text { compared to the previous year, } \%\end{array}$ & $\mathrm{x}$ & 74.2 & 104.3 \\
\hline 2.3 & $\begin{array}{l}\text { Share of corporate income tax expenses } \\
\text { from corporate income tax revenues, } \%\end{array}$ & 12.3 & 7.9 & 7 \\
\hline 3 & $\begin{array}{c}\text { The amount of tax receipts on the } \\
\text { property of organizations, thousand } \\
\text { rubles }\end{array}$ & $260,636.1$ & $342,555.2$ & $457,510.3$ \\
\hline 3.1 & $\begin{array}{c}\text { The amount of tax expenses from use of } \\
\text { reduced rates for property tax of } \\
\text { organizations }\end{array}$ & 587,568 & 651,439 & 362,106 \\
\hline 3.2 & $\begin{array}{l}\text { Growth rate of the amount of tax } \\
\text { expenses on property tax of } \\
\text { organizations compared to the previous } \\
\text { year, } \%\end{array}$ & $\mathrm{x}$ & 110.9 & 55.6 \\
\hline 3.3 & $\begin{array}{c}\text { Share of tax expenses on corporate } \\
\text { property tax from corporate property tax } \\
\text { receipts, } \%\end{array}$ & 225.4 & 190.2 & 79.1 \\
\hline 4 & $\begin{array}{l}\text { The amount of transport tax receipts, } \\
\text { thousand rubles }\end{array}$ & $118,768.5$ & $131,104.6$ & $155,371.2$ \\
\hline 4.1 & $\begin{array}{l}\text { The amount of tax expenses from the } \\
\text { use of reduced tax rates for transport tax }\end{array}$ & 13,146 & 12,772 & 11,775 \\
\hline 4.2 & $\begin{array}{l}\text { Growth rate of the amount of provided } \\
\text { tax expenses for transport tax compared } \\
\text { to the previous year, } \%\end{array}$ & $\mathrm{x}$ & 97.2 & 92.2 \\
\hline 4.3 & $\begin{array}{l}\text { Share of tax expenses on transport tax } \\
\text { from transport tax revenues, } \%\end{array}$ & 11.1 & 9.7 & 7.6 \\
\hline 5 & $\begin{array}{c}\text { The amount of tax receipts under the } \\
\text { simplified taxation system, thousand } \\
\text { rubles }\end{array}$ & $290,691.7$ & $361,834.1$ & $391,170.1$ \\
\hline 5.1 & $\begin{array}{l}\text { The amount of tax expenses from the } \\
\text { use of reduced tax rates under the } \\
\text { simplified taxation system }\end{array}$ & 23,176 & 18,681 & 21,888 \\
\hline 5.2 & $\begin{array}{c}\text { Growth rate of the amount of provided } \\
\text { tax expenses under the simplified } \\
\text { taxation system compared to the } \\
\text { previous year, } \%\end{array}$ & $\mathrm{x}$ & 80.6 & 117.2 \\
\hline 5.3 & $\begin{array}{l}\text { Share of tax expenditures under the } \\
\text { simplified taxation system from tax } \\
\text { revenues under the simplified taxation } \\
\text { system, } \%\end{array}$ & 8 & 5.2 & 5.6 \\
\hline 6 & $\begin{array}{c}\text { The amount of tax receipts under the } \\
\text { patent taxation system, thousand } \\
\text { rubles }\end{array}$ & $1,456.7$ & $1,699.8$ & $1,906.4$ \\
\hline 6.1 & $\begin{array}{l}\text { The amount of tax expenses from use of } \\
\text { reduced tax rates under the patent } \\
\text { taxation system }\end{array}$ & 1,103 & 902 & 339 \\
\hline 6.2 & $\begin{array}{l}\text { Growth rate of the amount of provided } \\
\text { tax expenses under the patent taxation } \\
\text { system compared to the previous year, } \\
\%\end{array}$ & $\mathrm{x}$ & 81.8 & 37.6 \\
\hline
\end{tabular}


Continuation of Table 2.

\begin{tabular}{|c|c|c|c|}
6.3 & $\begin{array}{c}\text { The share of tax expenditures under the } \\
\text { patent taxation system from tax } \\
\text { revenues under the patent taxation } \\
\text { system }\end{array}$ & 75.7 & $53, .1$ \\
\hline
\end{tabular}

The data in Table 2 show a significant decrease in the share of tax expenditures from tax revenues for which tax incentives are granted. For example, the share of tax expenses incurred on income tax in the total revenues from this tax in 2017 was $12.3 \%$, in 2018 $7.9 \%$, in $2019-7 \%$.

It shall also be noted that the ratio of tax expenditures to revenues from corporate property tax has decreased. In 2017, tax expenses exceeded the tax revenue indicator by $326,931.9$ thousand rubles, or $225.4 \%$. In 2018, the share of tax expenses decreased to $190.2 \%$ (308,884 thousand rubles). In 2019 there was a sharp decrease in the said indicator: the share of tax expenses on property tax from tax revenues amounted to only $79,1 \%,(95,404.3)$ thousand rubles.

Therefore, the cancellation of ineffective tax incentives for the tax on the property of organizations has a positive effect on the budget of the subject, expressed by an increase in revenues from this tax.

Let us emphasize the main conclusion contained in the above-mentioned report of the Ministry of Finance of the Altai Republic on the assessment of the effectiveness of tax expenditures for 2019. Ultimately, tax incentives at the regional level have an undoubted positive social, budgetary and economic effect.

\section{Discussion of Results}

In the course of the analysis of the tax policy of the Altai Republic in terms of providing tax benefits, it was found that tax benefits and preferences in the region are provided for income tax, for corporate property tax, for transport tax in the form of reduced tax rates. In the framework of the simplified and patent taxation systems, benefits are implemented in the form of tax exemptions.

It shall be noted that the Altai Republic is considered one of the poorest regions of the country. In our opinion, in order to improve the socio-economic situation in the republic, it is necessary to more intensively stimulate small and medium-sized businesses in the form of reduced rates or exemption from taxation. Development of small and medium-sized businesses is, first of all, creation of jobs, competition, and hence a reduction in prices, and, of course, tax receipts to the regional budget. Considering the above, it is necessary to add tax benefits under the simplified taxation system for payers engaged in socially significant activities. It is advisable to support not only newly registered entrepreneurs, but also those who actually carry out activities for a certain period of time.

Therefore, the tax incentives used in the modern Russian tax system shall not be canceled, but reformed on the basis of a systematic approach, their economic effect shall be calculated and the selective nature and targeted use of the privileged funds shall be controlled.

\section{Conclusion}

Tax incentives are an essential element of state regulation of the activities of large and small enterprises, private entrepreneurs and the real income of individuals. Provision of tax incentives for regional taxes leads to a drop in revenues for the budgets of the territory, however, with the right direction, they provide a positive social and economic effect. 
It has been established that the correct development and application of a systematic approach in the course of assessing the effectiveness of tax incentives will allow solving a number of problems:

1) ensuring transparency of the budgetary and tax policy of the constituent entities of the Russian Federation;

2) formation of a complete understanding of use of budgetary resources of the constituent entities of the Russian Federation in the context of the goals of state policy;

3 ) increasing the effectiveness of measures of socio-economic policy of the constituent entities of the Russian Federation on the basis of an informed choice of the optimal way to achieve goals;

4) improving the quality of forecasting revenues of the budgets of the budgetary system.

In order to improve the regional tax policy, we have proposed the following recommendations in terms of increasing the efficiency of the application of tax incentives:

- it is necessary to differentiate tax rates for the tax on the property of organizations, since if the organization has expensive real estate, the provision of tax benefits for the above tax in the form of a zero rate is ineffective and entails great damage to the regional budget. Therefore, in our opinion, it is considered fair to provide a tax incentive on property tax of organizations in the form of a reduced tax rate of up to $1.1 \%$, to organizations whose fixed assets value exceeds 300,000 thousand rubles.

- to overcome the disproportionality of investment contributions to the amount of tax benefits provided by the region, which leads to the interest of taxpayers in obtaining tax benefits through application of tax benefits, in this regard, it is necessary to increase investment contributions. Namely, to determine a specific methodology for calculating investment contributions, taking into account the financial and labor resources of each organization.

- it is necessary to make the procedure for including taxpayers in the register of social investors more transparent, i.e. publish on the official websites lists of organizations, selection conditions, competition results, as well as publish reports on the development of investment contributions.

\section{References}

1. Nalogovyj Kodeks Rossijskoj Federacii (ch. 1), st. 8. «Ponyatie naloga, sbora, strahovyh vznosov». Access mode: http://www.consultant.ru/

2. Nalogi i nalogovoe pravo: Uchebnoe posobie (1998)

3. Nalogovye l'goty. Teoriya i praktika primeneniya: monografiya dlya magistrantov, obuchayushchihsya po programmam napravleniya «Finansy i kredit» (2014)

4. Nalogi $i$ nalogooblozhenie: uchebnik $i$ praktikum dlya prikladnogo bakalavriata (2018)

5. Teoriya i istoriya nalogooblozheniya: Uchebnoe posobie (2006)

6. Postanovlenie Pravitel'stva RA ot 14.08 .2018 g. №257 «Ob osnovnyh napravleniyah byudzhetnoj i nalogovoj politiki Respubliki Altaj na 2019 god i na planovyj period 2020-2021gg». Access mode: https://minfin-altai.ru/deyatelnost/normativnyepravovye-akty-po-formirovaniyu-i-ispolneniyu-byudzheta/osnovnye-napravleniyanalogovoy-byudzhetnoy-dolgovoy-politiki/byudzhetnaya-i-nalogovaya-politika.php

7. Oficial'nyj sajt UFNS Rossii po Respublike Altaj. Access mode: https://www.nalog.ru/rn04/apply_fts/

8. Oficial'nyj sajt Ministerstva finansov Respubliki Altaj. Access mode: https://www.minfin-altai.ru/ 
9. R. Adarina, Y. Gazukina, K. Yankovskaya, Indicators of the green economy as a tool for monitoring the regional economy, IOP Conference Series: Earth and Environmental Sciencethis link is disabled, 395(1) (2019)

10. T. A. Kuttubaeva, L. V. Ishhuk, A. V. Glotko, E. O. Chernova, M. G. Suhova, Economic and environmental marketing in establishment of tourist territories. Exemplified by the Republic of Altai, Journal of Environmental Management and Tourismthis link is disabled, 9(2), 376-389 (2018) 